\title{
SEJARAH PERADABAN ISLAM DI CINA DAN NILAI-NILAI PENDIDIKAN ISLAM DALAM NOVEL ASSALAMUALAIKUM BEIJING
}

\author{
Dwi Masdi Widada \\ UIN Maulana Malik Ibrahim Malang \\ e-mail: widoke_11@yahoo.co.id
}

\begin{abstract}
The phrase that describes that a science should be pursued even to China. Novel Assalamualaikum Beijing provides an overview of the presence of Islam in the Bamboo Curtain country. Islamic civilization has appeared some time ago in China. The novel is intentionally prove that Islam was, and triumphed in China. Islam not only had triumphed in Europe, especially Andalusia (now Spain). Travelling around the main character of China as a columnist Asma Indonesia provided a glimmer of hope, strength, and love of the teachings of Islam. Islam never lived and interacted with the people of China. Chinese Muslim faces with hoods and eyes sipitnya show relationships and interactions among the Muslims. Islam in China is known as "pure religion of the sky" .In this novel, the reader is also treated to the values of Islamic education, the history of Islam, and the messages of Islam. Building a mosque in China a sign of the existence of Islam. One of the mosques and Muslim villages in China. This shows the triumph of Islam in the past. The value of education and the propagation of Islam seen in self Zhongwen figures. He was fascinated with friends Mus'ab bin Umair handsome and willing to remove the sparkling world for his new love in Islam
\end{abstract}

Keywords: Islamic Civilization, Islamic Education Value, China

\begin{abstract}
Abstrak: Tuntutlah ilmu sampai ke negeri Cina. Itulah ungkapan petuah Arab yang sering kita dengar. Ungkapan yang menggambarkan bahwa sebuah ilmu pengetahuan harus dikejar walau sampai ke negeri Cina. Novel Assalamualaikum Beijing ini memberikan gambaran tentang keberadaan Islam di negeri Tirai Bambu. Peradaban Islam sudah muncul beberapa waktu silam di Cina. Novel ini sengaja membuktikan bahwa Islam pernah ada dan berjaya di Cina. Islam tidak hanya pernah berjaya di Eropa, terutama Andalusia (sekarang Spanyol). Perjalanan tokoh utama Asma mengelilingi Cina sebagai kolumnis Indonesia memberikan secercah harapan, kekuatan, dan kecintaan pada ajaran Islam. Islam pernah bermukim dan berinteraksi dengan masyarakat Cina. Wajah-wajah muslim Cina dengan kerudung dan mata
\end{abstract}


sipitnya memperlihatkan hubungan dan interaksi sesama muslim. Islam di Cina dikenal sebagai "agama murni dari langit”.Dalam novel ini, pembaca juga disuguhi nilai-nilai pendidikan Islam, sejarah Islam, dan pesan-pesan dakwah Islam. Bangunan masjid di Cina menjadi tanda keberadaan Islam. Salah satu masjid dan perkampungan muslim di Cina. Hal ini memperlihatkan adanya kejayaan Islam di masa lalu. Nilai pendidikan dan dakwah Islam terlihat pada diri tokoh Zhongwen. Ia terpesona dengan sahabat Mus'ab bin Umair yang rupawan dan rela melepas gemerlap dunia demi cinta barunya pada Islam.

Kata-Kata Kunci : Peradaban Islam, Nilai Pendidikan Islam, Cina

\title{
Pendahuluan
}

\author{
Ajaklah mereka kepada Islam. Jika mereka memenuhi \\ ajakanmu, terimalah mereka dan cegahlah (tanganmu) untuk \\ memerangi mereka. Kemudian ajaklah mereka berhijrah dari negeri \\ mereka (dar al-kufr) ke negeri kaum Muhajirin (dar-almuhajirin) \\ (H.R. Muslim)
}

Orang boleh pandai setinggi langit tetapi selama tidak menulis, ia akan hilang dari sejarah (Pramoedya Ananta Toer)

Mengutip kata-kata George Santayana: "Those who don't learn from history are doomed to repeat it." Barang siapa melupakan sejarah, dia pasti akan mengulanginya. Banyak di antara umat Islam kini yang tidak lagi mengenali sejarah kebesaran Islam pada masa lalu. Tidak banyak yang tahu bahwa luas teritorial kekhalifahan Umayyah hampir dua kali lebih besar daripada wilayah Kekaisaran Roma di bawah Julius Caesar.

Islam bukan sekedar agama ritual. Islam memiliki sistem tersendiri yaitu sebuah sistem yang didasari pada Al-Qur'an dan perilaku Rasulullah SAW. Sistem inilah yang akhirnya membuat Islam berkembang denga pesat hingga menguasai wilayah yang begitu luas meliputi Jazirah Arab, Afrika, Andalusia, Irak, Persia, India, Afganistan, dan terus ke utara hingga mencapai wilayah Cina. Hal ini dapat dilihat dari nilai-nilai peninggalan sejarah berupa masjid bangunan yang berciri khas Islam. Belum pernah ada peradaban di dunia yang dengan 
waktu singkat memperoleh kegemilangan, bahkan suatu saat islam dapat mengusai dunia.

Cina sebagai negeri yang aktif dalam perdagangan internasional menyebabkan pedagang-pedagang muslim dari Arab melakukan perdagangan ke Cina sambil menyebarkan Islam di berbagai wilayah yang disinggahi. Adapun perjalanan yang dilalui dalam persebaran Islam di Cina adalah dengan melalui perjalanan darat dan laut. Perjalanan darat dimulai dari daratan Arab sampai ke bagian barat Laut Tiongkok dengan melewati Persia dan Afganistan. Jalan ini terkenal dengan nama jalan sutra atau silk road (Badri, 1993: 55). Akibat dari interaksi yang dilakukan mereka dengan pedagangpedagang lain termasuk pedagang Cina, ada semacam bentuk pengenalan kehidupan negeri asal pedagang-pedagang tersebut baik dari segi sosial, budaya maupun agama, termasuk pengenalan yang dilakukan pedagang-pedagang muslim mengenai Islam.

Pedagang-pedagang Cina yang berinteraksi dengan pedagangpedagang muslim sedikit banyaknya menerima kehadiran Islam. Mereka memeluk Islam sebagai agama mereka. Penyebaran Islam ini kemudian meluas hingga ke masyarakat Cina, khususnya wilayahwilayah yang digunakan sebagai pusat perdagangan. Masyarakat Cina yang telah memeluk Islam meminta pedagang-pedagang muslim untuk mengajarkan Islam lebih banyak lagi. Islam merupakan agama yang paling banyak memiliki sejumlah peradaban yang tersebar hampir di seluruh penjuru dunia. Rekam jejak sejarah Islam masa lalu tertulis dalam novel Assalamulaikum Beijing karya Asma Nadia.

Perjalanan yang panjang dilakukan tokoh Asma sebagai penulis kolom Indonesia yang ditempatkan di Cina memberikan keberkahan tersendiri untuk melihat sisa-sisa peradaban Islam di Negeri Tirai Bambu. Dunia mulai bersimpati dan terkesima terhadap Cina. Orang Cina mengenal Islam dengan sebutan Yisilan Jiao yang berarti agama yang murni. Masyarakat Cina menyebut Makkah sebagai tempat kelahiran "Ma-hia-wu" atau Nabi Muhammad SAW. Pada awalnya, pemeluk agama Islam terbanyak di Cina adalah para saudagar dari Arab dan Persia. Orang Cina yang pertama kali memeluk Islam adalah suku Hui Chi (Ahmad, 2003: 87). Sejak saat itu, pemeluk Islam di Cina kian bertambah banyak. Ketika Dinasti Song bertahta, umat Muslim 
telah menguasai industri ekspor dan impor. Bahkan, pada periode itu jabatan direktur jenderal pelayaran secara konsisten dijabat orang Muslim.

Jauh sebelum ajaran Islam diturunkan Allah SWT, bangsa Cina memang telah mencapai peradaban yang amat tinggi. Saat itu, masyarakat Negeri Tirai Bambu sudah menguasai beragam khazanah kekayaan ilmu pengetahuan dan peradaban. Tak bisa dipungkiri bahwa umat Islam juga banyak menyerap ilmu pengetahuan serta peradaban dari negeri ini. Beberapa contohnya antara lain, ilmu ketabiban, kertas, serta bubuk mesiu. Kehebatan dan tingginya peradaban masyarakat Cina ternyata sudah terdengar di negeri Arab sebelum tahun $500 \mathrm{M}$.

Karya sastra merupakan hasil renungan, baik pengalaman maupun imajinasi pengarang. Seorang pengarang selalu memperhatikan peristiwa hidup dan mencari ide-ide yang sesuai dengan situasi dan kondisi di jamannya. Pengalaman, ide dan gagasan adalah bentuk penerapan pengarang dalam menyesuaikan antara realitas dan karya sastra. Dari negeri Cina Inilah pengalaman tentang gambaran sejarah Islam diperoleh. Asma yang ditugaskan sebagai kolumnis Indonesia di Cina merasa takjub melihat bangunan masjid di Cina. Bentuk bangunan disesuaikan dengan budaya Cina. Ini merupakan bentuk akulturasi budaya. Dengan bantuan guide Asma dapat menelusuri jejak peradaban Islam di Cina.

\section{Masalah dan Teori}

Pada dasarnya karya sastra selalu memberikan kesenangan pada pembaca sebagaimana yang diungkapkan oleh Horance bahwa seni sastra adalah dulce et utile, artinya menyenangkan dan bermanfaat (Wellek dan Waren, 1990:25). Karya sastra merupakan cipta karya imajinatif yang mengungkapkan tentang masalah-masalah manusia dan kehidupan. Pengarang akan menampilkan nilai-nilai yang lebih tinggi dan agung dengan penfsiran makna hidup. Novel sangat digemari di kalangan remaja dan para pecinta sastra. Ada pesan tersirat dalam sebuah novel. Selain menyenangkan, karya sastra juga bermanfaat bagi pembacanya. Novel Assalamualaikum Beijing memperlihatkan nilai-nilai pendidikan Islam dan jejak-jejak peradaban Islam di negeri Cina. Negeri Tirai Bambu di benua di Asia dipandang 
oleh masyarakat sebagai negeri komunis. Sama halnya dengan Eropa, muncul kesan tidak percaya bahwa Islam pernah berjaya di sana. Para sejarawan mulai terbuka pemikirannya tentang sejarah Islam masa lalu. Sebagai karya sastra yang monumental, novel dapat menggugah semangat dan rasa simpati, empati saat membaca dan merenungkan. Ada nilai-nilai kesejarahan dan pendidikan yang dapat ditelusuri dalam novel Assalamualaikum Beijing.

Permasalahan yang dapat dikaji dalam novel Assalamualaikum Beijing adalah apa saja nilai-nilai pendidikan Islam dan sejarah peradaban Islam yang berada di sekitar wilayah benua Asia. Kawasan sekitar benua tersebut menjadi bagian dari proses penyebaran Islam yang dimulai dari Jaziah Arab. Pengarang menulis novel Assalamualaikum Beijing karena pengarang ingin mengekspresikan semua imajinasinya melalui novel seperti kesetiaan, pengorbanan, pendidikan, dan sejarah perkembangan Islam. Tujuan mengaji novel ini adalah untuk mengenalkan kembali kepada masyarakat dunia bahwa agama Islam pernah berjaya. Di samping itu, novel ini memberikan gambaran kepada para peminat sejarah bahwa sisa-sisa peradaban Islam berupa masjid masih berdiri kokoh dan dipergunakan masyarakat muslim di Cina hingga sekarang.

Nilai-nilai pendidikan Islam menjadi bagian penting dalam menghidupkan alur novel ini. Pengarang memberikan gambaran tentang fenomena keberadaan Agama Islam dibalut dengan kesetiaan dan cinta. Faktor keberadaan Islam di Cina merupakaan bagian dari sejarah Islam masa lalu. Hal ini dibuktikan dengan perkembangan mayoritas muslim Cina dan berbagai peninggalan masjid dengan perpaduan antarbudaya.

\section{Metode}

Penelitian ini menggunakan metode analisis kepustakaan dengan pendekatan kualitatif. Pendekatan kualitatif merupakan pendekataan penelitian yang dilakukan dengan tidak menggunakan angka, tetapi kedalaman penghayataan terhadap interaksi antar konsep yang dikaji secara empiris (Semi 2008: 4-5). Analisis penelitiaan ini menitikberatkan pada aspek pendidikan Islam sejarah peradaban Islam. Kemunculan dan bukti-bukti kejayaan Islam masa lalu. Sebuah 
pendekataan dengan mengedepankan nilai-nilai Islam jika dikaitkan dengan masa sekarang. Sumber penelitian ini adalah kajian pustaka pada novel Assalamualaikum Beijing.

Data penelitian diambil dari novel Assalamualaikum Beijing karya Asma Nadia. Data tersebut dianalisis secara ekstrinsik dengan pendekataan kualitatif. Kemunculan nilai-nilai Islam yang bersumber dari perubahan peradaban di daratan Asia khususnya Cina. Metode pengumpulan data penelitian ini menggunakan metode pustaka atau dokumen. Metode pustaka diambil dari novel yang dikaji berkaitan dengan aspek kesejarahan dan perkembangan Islam yang melekat pada peradaban dunia.

Teknik analisis data penelitian ini menggunakan teknik analisis deskriptif dan teknik analisis isi (Rahmat, 2000: 45). Teknik analisis deskriptif adalah suatu teknik analisis untuk mendeskripsikan makna data sehingga menimbulkan kejelasan dan mudah dipahami oleh pembaca. Teknik analisis isi digunakan untuk menganalisis isi komunikasi secara sistematik dan objektif terhadap semua pesan berupa teks, simbol, gambar yang merupakan produk sosial budaya masyarakat setempat. David L Altheide mengatakan bahwa analisis isi kualitatif disebut pula sebagai Etnographic Content Analysis (ECA) yaitu perpaduan analisis objektif dengan observasi partisipan. Peneliti berinteraksi dengan material-material dokumentasi atau bahkan melakukan wawancara mendalam sehingga pernyataan-pernyataan yang spesifik dapat diletakkan pada konteks yang tepat untuk dianalisis.

Dalam penelitian ini, metode yang dipakai adalah menggunakan kajian analisis terhadap literatur yang relevan dengan pokok bahasan. Fakta berupa bukti peninggalan sejarah peradaban Islam sering terlihat di benua Asia bagian utara. Peninggalan berupa bangunan dan peradaban merupakan bagian penting dari bentuk dokumentasi peninggalan sejarah. Di samping itu beberapa wacana terkait dengan nilai-nilai historis dan tradisi Islam masa lalu. Kajian difokuskan pada objek penelitian berupa novel dan bahan-bahan dengan menelusuri jejak-jejak peradaban Islam novel Assalamualaikum Beijing karya Asma Nadia. Ada keterkaitan novel yang ditulis dengan nilai-nilai peradaban Islam masa lalu. 


\section{Hasil dan Pembahasan}

1. Sekilas tentang Novel Assalamualaikum Beijing

Novel Assalamualaikum Beijing merupakan kisah perjalanan menampaki jejak-jejak peradaban Islam di Benua Asia khususnya Cina. Novel ini ditulis oleh Asma Nadia. Tokoh utama dalam novel ini adalah Asmara, hampir mirip dengan nama penulisnya. Novel ini memang terinspirasi dengan perjalanan traveler, akan tetapi gaya penceritaaan dikemas dengan bernarasi imajinatif dengan sentuhan nilai-nilai kesejarahan.

Dari negeri Cina ini adalah awal mula kisah manis cerita Asma. Perjalanan Asma pergi ke Cina karena menggantikan temannya yang mendadak sakit. Ia bertugas sebagai kolumnis Indonesia untuk membuat berita terkait dengan perkembangan Islam di Cina, sehingga judul redaksi dikolomnya berita diberi nama Assalamualaikum Beijing. Judul ini memberikan kesan tersirat bahwa Islam berkembang di Cina. Kata sapaan "Assalamualaikaum Beijing" mengandung arti semoga selamat dan sejahtera tercurahkan kepada kalian semua. Mereka menyapa dan menyambut kehadiran perkembangan Islam dengan melihat sisa-sisa peninggalan kejayaan Islam di kota tersebut. Beijing sebagai ibukota Cina turut menyapa terutama pada suku minoritas muslim di sana.

Tanpa diduga, tokoh Asma sangat takjub dengan bukti peninggalan masa kejayaan Islam. Selama ini yang diketahui bahwa Cina merupakan negeri komunis. Ini memberikan kesan bahwa Asma ingin mengupas kembali nilai-nilai kesejarahan Islam lebih jauh pada jamannya di Cina. Ia berintekasi mencari bukti dan data-data layaknya seorang wartawan. Cina tidak hanya identik dengan negeri komunis. Kebudayaan Islam pernah menginjakkan kaki dan menyebarkan misi dakwah di Cina.

Selama berada di Cina, Asma berhasil menyihir Zhongwen untuk mengenalkan semua peninggalan yang terkait dengan sejarah dan peninggalan Islam. Demikian sebaliknya Zhongwen merasa kehadiran Asma di Cina membuka pintu hidayah untuk mengenal cahaya Islam. Ia lebih sering mengunjungi beberapa masjid termasuk masjid Niujie, masjid Xi'an, dan mengenal sosok sahabat Mush'ab bin Umair. 
Namun bagi ayahnya, ikatan darah bisa putus, ketika keyakinan tak lagi sama.

"kenapa bukan yang lain? Kenapa harus Islam?"

Hidayah.

Cahaya yang menuntunnya melalui Ashima.

AB: 253

Inilah cahaya dan hidayah yang datang pada diri Zhongweng. Hidayah itu datang dari Allah. Zhongweng merasa yakin untuk memeluk Islam. Ashima merupakan panggilan Asma bagi Zhongweng. Ia bersikukuh memanggil Ashma karena teringat cerita legenda patung Ashima dan Ahei. Kehadiran Asma membuka pintu hidayah bagi Zhongweng tentang ajaran-ajaran Islam. Ia bukanlah atheis. Ia mengakui keberadaan Tuhan, tetapi ia masih ragu dengan agamanya. Dengan perjalanan waktu ia pun menjadi muallaf dan mulai mempelajari kehidupan sahabat-sahabat rasululah SAW.

Disamping itu kesungguhan mempelajari Islam tertanam saat Zhongweng dikenalkan Imam masjid terhadap beberapa sahabat Rasullullah SAW. Sahabat tersebut bernama Mush'ab bin Umar.

Zhongwen yakin, hanya iman yang memberikan keberanian sejati. Iman yang menggerakkan Mush'ab bin Umar untuk membacakan ayat-ayat Al-Qur'an yang didengarkan dari Rasulullah, dan bukan bersembunyi ketakutan dan panik.

Iman telah mengubah seorang Mush'ab. Belum hilang dari ingatan bagaimana mewah dan wangi penampilan pemuda itu masuk Islam.

Namun, Mush'ab yang saat itu berdiri di hadapan mereka mengenakan jubah usang bertambal-tambal. Pemandangan kontras yang melahirkan senyum dan kasih sayang di wajah Rasulullah ketika berkata,

AB: 258-259 
Melihat sosok sahabat Mush'ab bin Umar sebelum masuk Islam menjadikan tolok ukur bahwa dunia menjadi tidak ada sama sekali dibandingkan dengan hidayah dan keimanan dalam memeluk Islam. Cerita yang diberikan Imam masjid Xi'an pada tokoh Zhongwen menjadi bukti dan kekuatan untuk menjadi muallaf. Sang Imam menceritakan bagaimana sahabat bernama Mush'ab bin Umar melepaskan semua kemewahan dunia demi kecintaan pada Islam. Dalam sebuah cerita, tantangan yang ditakuti Mush'ab bin Umar nyaris tidak ada. Bahkan jika seisi kota Mekkah beserta pembesar hendak menyerangnya, ia pun tak takut. Ia berani melepas dan meninggalkan semua harta benda yang selama ini menjadi kemewahan sebelum ia memeluk Islam.

Zhongwen baru mengenal nama tersebut, tetapi ia tergugah dengan keimanan yang dimiliki Mush'ab dalam membela agama Islam. Di perang Uhud, Mush'ab tidak gentar bahkan ketika Ibnu Qumaimah dengan menunggang kuda datang dan menebas tangan Mush'ab hingga putus, ia tetap membawa bendera Islam. Ketulusan penulis untuk membagikan pengalamannya akan mengingatkan dan menumbuhkan kembali rasa bangga menjadi seorang muslim dan betapa indahnya agama Islam.

2. Sekilas Tokoh dalam Novel 99 Cahaya di Langit Eropa

1. Asmara

Asmara, tokoh ini biasa dipanggil Ra oleh Dewa. Asma adalah kekasih Dewa sejak duduk di bangku kuliah. Hubungan mereka tinggal selangkah lagi menuju gerbang pernikahan. Namun, tidak disangka hubungan mereka berdua berakhir. Karena pada saat itu Dewa dan Anita telah berselingkuh. Harapan dan rencana ke pernikahan pun berakhir. Beberapa bulan yang akan datang Asma pergi ke Beijing. Keberangkatan ke Beijing adalah tugasnya sebagai kolumnis Indonesia menggantikan temannya yang sakit.

Di kota Beijing, Ia bertemu dengan seseorang laki-laki bernama Zhongwen. Seseorang laki-laki tersebut akan menjadi narasumber kolom tentang keberadaan komunitas muslim Cina dan peninggalan kebudayaan Islam di Cina. Zhongwen juga memperkenalkan legenda cinta Ashima yaitu seseorang putri cantik yang berasal dari Yunnan. 
Zhongwen memanggil Asma dengan sebutan Ashima. Karena kebaikan dan ketulusan hati Zhongwen, Asma pun perlahan-lahan membuka hati dan mengajarkan Zhongwen tentang Islam.

2. Dewa

Dewa adalah kekasih Asma sejak duduk di bangku kuliah. Hubungan mereka tinggal selangkah lagi menuju gerbang pernikahan. Namun, tidak disangka hubungan mereka berdua berakhir. Dewa dan Anita telah berselingkuh. Dewa merasa bersalah kepada diri sendiri dan Ra (panggilan Dewa kepada Asma). Ia terpaksa menikahi Anita yang sedang hamil akibat berbuatannya tersebut.

Kejadian yang tidak diduga. Anita merebut Dewa dari Ra. Pada saat itu hujan deras dan udara yang tidak mendukung, Dewa terpaksa menghantarkan Anita dan menginap ditempatnya. Awalnya Dewa pun menolak untuk menginap dan menemani Anita. Anita adalah teman sekantor Dewa. Dewa merasa kasihan. Akhirnya Dewa pun menemani Anita dan menginap dirumahnya.

Di dalam hati dan pikiran Dewa, masih tersimpan Ra. Ia masih menginginkan dan berharap Ra kembali walaupun hal itu tidak mungkin karena Dewa sudah menikahi Anita. Dewa tetap bersikeras sampai mengejar Asmara ke negeri Cina. Dewa pun berniat akan menceraikan Anita. Kerja keras dan pengorbanan Dewa menjadi siasia. Hati dan pikiran Asma sudah tetutup.

\section{Zhongweng}

Zhongwen adalah orang Cina. Ia dikenal sebagai pemuda tampan dan jangkung. Ia bekerja sebagai pemandu wisata. Ia seringkali mengantarkan beberapa turis asing untuk memperkenalkan wisata dan budaya di Cina. Pertemuan dengan Asma di bus menjadikan pertemuan terus berlanjut. Ia menjadi pemandu wisata dan salah satu narasumber Asma selama di Beijing. Di pertemuan tersebut, Zhongwen teringat dengan legenda Ashima. Ia bersikukuh memanggil Asma dengan sebutan Ashima. Ashima adalah adalah gadis dalam legenda,orang tuanya berharap Ashima tumbuh menjadi gadis cantik seperti bunga dan bersinar kemilau seperti emas. Ashima legenda dari Yunnan.

Zhongwen memperkenalkan kebudayaan dan peninggalanpeninggalan Islam berupa masjid, dan beberapa komunitas 
perkampungan muslim di Cina. Perkenalan dengan Asma membuat Zhongwen selalu ingin mengetahui berbagai topik permasalahan tentang Islam. Sebagai peemandu wisata Ia hanya sekadar menemani melihat-lihat kebudayaan yang ada di Cina khususnya Islam tanpa mengetahui lebih jauh tentang Islam. Ia bukan atheis, ia percaya Tuhan tetapi ragu dengan agamanya. Dengan hadirnya Asma, Zhongwen mulai belajar tentang nilai-nilai keislaman dan mengantarkannya menjadi muallaf. Ia belajar mendalami Islam dan dikenalkan juga oleh Imam masjid tentang sosok sabahat Rasul bernama Mush'ad bin Umar.

4. Sekar

Sekar adalah teman Asma di Beijing. Ia merupakan rekan kerja di Korespondensi Indonesia di Beijing. Sekar merasa senang saat Asma dikirim ke Beijing menggantikan rekan teman di Indonesia yang saat itu sedang sakit. Kisah Asma dengan Dewa sudah diketahui oleh Sekar. Sekar merupakan teman sekaligus sahabat dekat Asma. Segala keluh kesah Asma tercurahkan dan disampaikan lewat surat elektronik, sehingga permasalahan Asma di Indonesia sudah menjadi bagian dari hidup Sekar. Sekar dan suaminya bekerja di Korespondensi Indonesia di Beijing.

Keberadaan Sekar di Beijing memberikan semangat Asma untuk memulai hidup baru. Bahkan Sekar memotivasi Asma. Siapa tahu di Beijing Asma bertemu jodoh. Ucapan ini tidak ditanggapi serius oleh Asma. Keberadaan Sekar juga dibutuhkan saat Asma mengidap penyakit APS (Antiphosholid Syindrome) Sindrom darah kental. Setiap saat terjadi gumpalan darah. Sekar hadir di situ menemani dan memberikan semangat Asma. Kondisi kritis menjadikan sekar menangis melihat keteguhan dan pengorbanan Asma untuk terus hidup.

3. Sejarah Perkembangan Islam di Cina

Islam memiliki catatan sejarah yang penting di Cina. Di Negeri Tirai Bambu tersebut, Islam telah masuk dan mewarnai kehidupan masyarakat sejak abad ke-7 Masehi. Ini berarti sudah lebih 14 abad yang lalu Islam berkembang di Cina. Tuntutlah ilmu sampai ke negeri Cina. Itulah ungkapan petuah Arab yang sering kita dengar. Ungkapan yang menggambarkan bahwa sebuah ilmu pengetahuan harus dikejar walau sampai ke negeri Cina. Tak heran bila hingga kini, cukup banyak 
penduduk Cina yang beragama Islam. Kendati tak sebesar Indonesia, masyarakat muslim di Cina sangat taat dalam menjalankan ibadahnya. Bahkan, di sejumlah daerah, terdapat perkampungan muslim. Di Cina, terdapat beberapa suku bangsa yang beragama Islam, termasuk etnik Huizu, Uygur, Kazakh, Kirgiz, Tajik, Uzbek, Tatar dan lain-lainnya. Penduduk Islam merata tinggal di seluruh China, terutamanya di bagian barat laut.

Ketika masa khalifah Utsman bin Affan, beliau meminta kepada paman Rasulullah, Sa'ad bin Abi Waqqash secara pribadi untuk membangun hubungan dengan negara Cina. Dengan misi mendakwahkan agama Islam, shahabat Sa'ad diterima dengan sangat baik oleh Kaisar pada dinasti Tang. Ia membawa salinan Al-Qur'an dan menyebarkan ke berbagai tempat demi menjaga kemurnian kitab suci. Cina mencapai kejayaan peradaban sehingga sangat mudah menerima Islam. Setelah menerima Sa'ad bin Abi Waqqash, kaisar memerintahkan untuk membangun masjid bernama Huaisheng (Memorial Mosque) di kota Guangzhou untuk menjadi kenangan dan tanda sepakatnya kepada Islam.

Pada awalnya, pemeluk agama Islam terbanyak di Cina adalah para saudagar dari Arab dan Persia. Mereka bercampur dengan orangorang Cina, mereka dijuluki sebagai orang-orang Hui. Di Cina ada banyak kelompok. Kelompok terbesar yang biasanya kita sebut orang Cina adalah kelompok Han. Han adalah orang-orang berperawakan Cina yang sering kita lihat, tapi Han adalah mayoritasnya. Dan umat Muslim bercampur dengan para Han dan mereka sekarang dikenal sebagai Hui. Masyarakat Cina muslim dikenal dengan sebutan kelompok Hui. (Alwi, 2001:90-92). Kelompok Hui adalah warga yang tersebar di beberapa daerah yang berpenduduk Hui baik secara fisik dan bahasa. Kelompok ini tidak menganggap dirinya sebagai warga Cina disebabkan mereka tidak makan daging babi, menyembah nenek moyang, tidak berjudi, tidak mengonsumsi minuman keras, dan tidak pula mengisap ganja.

Pada jaman Dinasti Tang, Kaisar meminta bantuan Kerajaan Persia untuk mengutus pengajar-pengajar Islam ke Cina. Namun, Raja Persia menolaknya karena daratan Cina terlalu jauh untuk didatangi. 
Akibat dari penolakan tersebut, Kaisar mengutus orang-orang Cina untuk belajar Islam di Madinah.

Pada jaman Dinasti Song, agama Islam dianggap lebih mulia oleh rakyat Cina. Sang kaisar mengundang 5.500 Muslim dari Bukhara. Agama Islam telah mulai berkembang di Cina dan kawasan kediaman penduduk beragama Islam lebih luas. Kaisar menempatkan para muslim dalam jabatan untuk urusan perdagangan mereka. Muslim merupakan kunci perdagangan. mereka dapat dipercaya. rang-orang Cina melihat bahwa menggunakan umat muslim bermanfaat bagi mereka dan juga bagi umat uslim. Mereka juga menghormati Islam. Banyak orang asing yang beragama Islam tinggal di bandar Guangzhou di provinsi Guangdong dan bandar Quanzhou di provinsi Fujian. Beberapa masjid pada zaman Dinasti Song yang masih ada sekarang sudah tidak banyak, yang paling terkenal ialah masjid "Qing Jing Si" dibandar Quanzhou.

Jaman Dinasti Yuan merupakan jaman yang paling penting bagi perkembangan agama Islam di Cina. Agama Islam di Cina berkembang paling pesat dan paling makmur. Muslim mempunyai kedudukan yang penting di arena politik dan kehidupan masyarakat. Penduduk yang menganut agama Islam bertambah pesat. Suku Hui Cina banyak mengadakan perhubungan dengan dunia Arab. Masjid bertambah banyak. Selain bercirikan seni Arab, Masjid di Cinareka bentuknya mencirikan seni Cina dengan berbagai macam kayu diukir.

Pada jaman Dinasti Ming, perkembangan agama Islam di Cina telah menghadapi rintangan. Maharaja pertama Dinasti Ming memandang rendah terhadap agama Islam. Baginda mengeluarkan perintah untuk melarang rakyat menyembelih lembu secara tersendiri dan beberapa dasar yang mendiskriminasi umat Islam, termasuk orang Islam tidak boleh menjadi pegawai kerajaan dan lain-lainnya. Ini telah mencetuskan kemarahan umat Islam di Cina dan penduduk Islam mengadakan pemberontakan di ibu kota negara.

4. Bukti dan Jejak Peradaban Islam di negara Cina

Beijng merupakan ibukota Cina. Di negara ini, Asmara mendapat tugas sebagai kolumnis Indonesia. Ia menggantikan rekan kerja karena mendadak sakit. Kepergian ke Beijing juga merupakan hikmah dari beberapa peristiwa masa lalu dengan Dewa saat di Indonesia. Sebagai 
penulis kolom Indonesia, Asma ingin menelusuri keberadaan Islam di negeri tirai bambu. Di mulai dari komunitas muslim di Cina dan jejak-jejak peninggalan Islam masa lalu di Cina. Islam adalah agama universal, yang bisa diterima oleh semua golongan; suku, bangsa, dan adat istiadat. Islam cepat diterima masyarakat karena prinsip toleran (tasamuh), moderat (tawasuth), berkeadilan, dan seimbang (tawazun). Islam disambutan gembira dan terbuka di negeri Cina.

a. Masjid Niu Jie

Masjid ini sangat terkenal di ibu kota Cina, Beijing. Bisa dikatakan masjid ini merupakan pusat komunitas muslim di sana. Dalam sejarahnya, Masjid Niujie menjadi titik awal masuknya Islam ke Cina.

Laki-laki itu tak ingin berbohong, apa yang
disampaikannya memang benar. Namun
Ashimanya tentu tak perlu tahu bahwa dia telah
dengan sengaja mencari gadis itu ke sana ke mari.
"Do you know how old this mosque is?" tanyanya
mengalihkan keheranan
"A thousand years?"
Zhongwen mengangguk, "More than a thousand
years. It was build in 996".

AB: 97

Dengan bahasa Inggris, Zhongwen menjelaskan bahwa masjid ini bernama Niujie. Masjid ini dibangun pada 996 Masehi. Jika ditelusuri masjid ini dibangun pada masa pemerintahan Tonghe dari Dinasti Liao. Masjid Niujie terletak di Niujie (Jalan Sapi), Distrik Xuanwu, Beijing. Ini merupakan saah satu masjid di Beijing, ibu kota Cina tersebut. Arsitektur masjid ini mirip bangunan-bangunan Cina pada umumnya, tetapi ada nuansa-nuansa Arab dan Persia. Perbedaan beberapa bangunan kuil di Cina, kalau bangunan kuil menghadap ke selatan, sedangkan masjid di Cina menghadap langsung ke kiblat umat Islam di Mekkah.

Peninggalan Islam berupa masjid merupakan bagian dari adanya perkembangan Islam. Umurnya pun lebih dari 1000 tahun. Perjalanan 
Asma didampingi oleh Zhongwen memberikan nuansa tersendiri dengan melihat bangunan masjid Niujie.

\begin{abstract}
Setelah melalui pintu masuk, pengunjung akan berhadapan dengan watching moon tower, menara berbentuk heksagonal, setinggi lebih dari 10 meter. Bagian atasnya seperti rumah dengan atap keemasan.

"The tower is so named that way, because it was used by the imamto observe the position of the moon, to determine times for pasting".

Ah, Asma mengangguk.

Dari menara itu para imam mengawasi bulan untuk menentukan kapan Ramadhan pertama tiba.
\end{abstract}

AB: 98

Masjid Niujie juga dilengkapi dengan menara. Menara tersebut digunakan sebagai penentu awal puasa di bulan Ramadhan. Menara tersebut juga sering kali digunakan untuk mengumandankan adzan. Bentuk menara tersebut unik berbentuk heksagonal. Bangunan masjid pun tidak seperti bangunan masjid di Arab atau Timur Tengah. Bangunannya seperti rumah warga biasa dengan atap keemasan. Inilah bentuk-bentuk akulturasi budaya dalam penyebaran agama Islam di Cina.

b. Masjid Xi'an

Masjid Xi'an merupakan salah satu masjid di Cina. Masjid Raya Xi'an terbilang unik karena bentuk bangunannya lebih menyerupai kuil dibandingkan masjid. Keberadaan muslin Cina di Xi'an memberikan nuansa tersendiri.

"Kadang terselip rasa penasaran pemuda itu akan interior masjid, khususnya praying area. Sayang, nonmuslim dilarang masuk ke area shalat. Menurut temannya yang beragama Islam, 
ada sebuah catatan pada kayu yang terletak di bagian dalam masjid, yang menyebutkan bahwa Masjid Raya Xi'an didirikan tahun 742 Masehi atau sekitar tiga belas abad yang lalu.

AB: 42

Masjid ini terdapat di Kota Xi'an atau Chang'an. Zhongwen merasa penasaran dengan arsitektur masjid Xi'an. Ia bukan seorang muslim, sehingga ada aturan dan larangan di wilayah shalat bagi seorang nonmuslim. Masjid Xi'an didirikan pada 742 Masehi. Hal ini telihat pada catatan kayu di dalam interior masjid. Jika dirunut dalam sejarah, saat itu wilayah Cina berada di bawah Kaisar Xuanzong dari Dinasti Tang.

Bangunan masjid ini kemudian mengalami renovasi pada masa pemerintahan Kaisar Hongwu dari Dinasti Ming. Tidak seperti kebanyakan masjid di Timur Tengah atau negara Arab lainnya, Masjid Raya Xi'an memiliki konstruksi dan gaya arsitektur yang berbeda, kecuali untuk beberapa huruf Arab dan dekorasi yang terdapat pada bangunan masjid. Masjid ini tidak memiliki kubah-kubah atau menara yang bergaya.

Di kota kelahiranya, berdiri Masjid Raya Xi'an yang merupakan masjid tertua dan terbesar di Cina, dan menjadi jejak sejarah aktivitas dakwah para pedagang Arab dan persia yang berlayar melalui jalur sutra dan kemudian menetap di beberapa kota seperti Ghuangzhou, Quanzhou, Hanzhou, Yangzhou, dan Chang'an atau Xi'an.

\section{AB: 41}

Perlu direnungkan kembali bahwa peninggalan bersejaran Islam di Cina dapat terlihat jelas seperti bangunan Masjid. Masjid Raya Xi'an merupakan masjid tertua dan terbesar di Cina. Bahkan Masjid ini menjadi jejak para pedagang Arab dan Persia untuk berdakwah. Jalan ini terkenal dengan nama jalan sutra. Akibat dari interaksi-interaksi 
yang dilakukan, banyak pedagang dari Cina mulai dikenalkan nilai-nilai sosial, budaya dan kehidupan beragama Islam. Pedagang-pedagang Cina sedikit banyaknya menerima kehadiran Islam. Mereka memeluk Islam dan menamakan diri sebagai suku Hui.

c. Perkampungan Muslim di Cina

Komunitas muslim Cina menetap sebagai suku minoritas. Perkampungan Muslim yang sudah ada sejak sekitar 1.400 tahun lalu yang disebut 'Muslim Quarter' atau 'Hui People's Street, suatu kawasan yang mayoritas penduduknya adalah masyarakat suku Hui.

Padahal ini bukan kali pertama dia bertemu dengan gadis yang mengenakan kerudung. Mengingat Xi'an yang terletak di propinsi Shaaxi merupakan salah satu kota yang memiliki perkampungan muslim cukup besar yang dikenal dengan nama Hui Min Jie. Dalam sejarah, suku Hui merupakan perpaduan dan keturunan suku Han dengan Bangsa persia dan Arab, sejak Masa Dinasti Tang.

AB: 41

Gadis berkerudung yang dimaksud adalah Asma. Penampilan berkerudung layaknya seorang muslimah. Zhongwen teringat pula dengan sebuah perkampungan muslim di Cina. Awalnya muslim tersebut berasal dari Bukhara. Mereka bukan berasal dari orang Arab. Mereka dari Asia Tengah. Mereka berkerabat dengan orang Persia. Mereka bercampur dengan orang-orang Cina sehingga dijuluki sebagai orang-orang Hui Min Jie. Di Cina ada banyak kelompok-kelompok. Kelompok terbesar yang biasanya kita sebut orang Cina adalah kelompok Han. Han adalah orang-orang berperawakan Cina. Han adalah suku mayoritas. Umat muslim bercampur dengan para Han sehingga lebih dikenal sebagai suku Hui.

\section{Nilai-Nilai Pendidikan Islam}

Keberadaan novel Assalamualaikum Beijing tidak hanya memberikan gambaran tentang sisa-sisa peradaban Islam di Cina. 
Novel ini juga memberikan nilai-nilai pendidikan Islam. Pengarang berupaya memahami karakteristik tokoh utama dalam mengembang misi dakwah. Ada nilai-nilai pendidikan Islam yang menjadi teladan bagi pembaca.

a. Berjilbab adalah pelindung bagi muslimat untuk menjaga diri.

Melalui perenungan panjang, dia pun sampai pada keputusan untuk menjaga diri lebih baik. Mulai mengenakan jilbab, walaupun tak sepanjang Sekar. Asma juga mulai belajar mengikuti prinsip suami sahabatnya. Tidak bersalaman dan bersentuhan dengan lelaki, kecuali keluarga, dan tidak lagi pacaran. Tidak peduli jika menajdi perbinjangan di kanto. Asma menerimanya sebagai tantangan baru.

AB: $90-91$

Suatu keputusan tepat dilakukan Asma sebagai muslimah untuk menjaga diri. Dalam Islam pacaran tidak diperbolehkan. Islam menetapkan aturan keras terhadap kedekatan fisik laki-laki dan perempuan sebelum menikah. Tidak terhingga mudarat sebuah sentuhan jika dibiarkan sehingga dapat membuka pintu zina. Kadar dosanya dapat disejajarkan dengan dosa membunuh.

Dia menangkap kekagetan lelaki itu saat uluran tangannya mendapat sambutan berbeda. Bukan jabat tangan melainkan gaya salaman lain.

"I do it this way, usually'

Jelasnya sambil mengatupkan kedua tangan dn menyedekapkannya di depan dada.

It is your or all Indonesian muslim women do that?

What about a kiss an a cheek?

Asma menggeleng. Meskipun hanya satu ciumn di pipi.

No touch at all? 
Gadis itu mengangguk. Islam tak membenarkan laki-laki dan perempuan bersentuhan. Apa yang harus dilakukan seorang hamba selain memberikan kepatuhan kepada Rabb-Nya?

$\mathrm{AB}: 111$

Perkenalan antara Zhongwen dengan Asma menimbulkan tanda tanya. Asma hanya mengatupkan kedua tangan dan menyedekapkannya di depan dada. Apakah semua itu dilakukan oleh seorag muslimat. Mereka berdiskusi panjang lebar tentang makna persentuhan antara laki-laki dan perempuan dalam Islam. Pertanyaan tersebut memberikan rasa penasaran untuk mengenal lebih dekat makna ajaran Islam. Itulah bukti kecintan seorang muslim pada Allah. Jika aturan itu dilanggar maka berakibat pada dosa besar. Lebih baik seorang laki-laki memegang bara panas berapi daripada perempuan bukan mahromnya. Oleh karena itu seorang muslimat harus memakai penutup atau berjilbab. Berjilbab adalah hal yang wajib bagi muslimat dan merupakan bentuk solusi agar senantiasa menjaga diri. b. Hidayah itu berasal dari Allah SWT untuk umat yang dicintain-Nya

Lelaki berkulit kuning itu makin rajin ke perpustakaan. Menyibukkan diri dengan membaca buku-buku kajian tentang Islam, bahkan membeli Al-Qur'an dengan terjemahan bahasa Cina

\section{AB: 153}

Lelaki tersebut bernama Zhongwen. Hidayah bisa datang dari mana saja. Melalui perantara Asma, Zhongwen merasa ada keganjalan untuk menemukan agama yang penuh dengan cahaya. Ia bukan Atheis. Ia percaya pada Tuhan, tetapi ragu terhadap agamanya. Dari kebiasaan berdiskusi seputar kajian keislaman, Zhongwen lebih sering mamastikan dengan belajar lebih dalam tentang Islam..

Zhongwen baru mengenal nama itu. Belum lama. 
Namun, basah matanya, tergugah dengan keimanan begitu indah yang dimiliki lelaki itu, juga kecintaan dan pembelaan pada Rasulullah.

AB: 260

Imam masjid memperkenalkan sosok sahabat Mush'ab bin Umar kepada Zhongwen. Mush'ab berani mendermakan semua harta benda yang dimilikinya semasa itu untuk perjuangan agama Islam. Kecintaan inilah memberikan hidayah pada diri Zhongwen untuk memeluk agama Islam. Hidayah pun datang. Akhirnya Zhongwen menjadi masuk Islam dan menjadi muallaf.

c. Kekuatan doa menjadi senjata dan kunci utama seorang muslim.

Saat berada dalam perawatan dokter, Asma tetap bersemangat untuk betahan hdup. Penyakit yang diderita Asma adalah APS (Antiphosholid Syindrome) Sindrom darah kental. Setiap saat terjadi gumpalan darah dan ini berakibat pada aktivitas Asma.

Sekar membatu mencari bahan-bahan dari buku dan internet, lalu menyatukannya dalam satu file untuk di-print dn di-fotocopy.

"Doa selalu menenangkan dan memberi harapan", ujar Asma saat menerima kertas berisi catatan doa yang telah dicopy sahabatnya.

Bismillahisy syafi, bismillahil kafi, bismillahi mu'afi, bismillahi ladzi la yadurru ma'asmihi syai'un fil ardi wa la fis sama'I wa huwas sami'ul 'alim.

Inna massaniyad durru wa anta arhamur rahimiin.

AB: 153

Tanpa henti-hentinya Sekar menemani Asma terkait dengan beberapa doa agar Asma bersemangat dalam menghadapi segala ujian. Sikap Asma sebagi seorang muslim merasa tegar. Hanya lantunan doa menjadi semangat dan motivasi. Hidup adalah sebuah ujian. Semua ada di tangan Alla, kita tidak dapat menghidari dari skenario sang pencipta. 
Doa merupakan senjata seorang muslim untuk selalu bermunajat kepada Allah SWT. Dengan nama Allah, Tuhan yang menyembuhkan, dengan menyebut nama Allah Tuhan yang berkecukupan, dengan nama Allah yang dengan namaNya tidak ada sesuatu pun yang berbahaya baik di bumi maupun di langit. Dia adalah Tuhan yang Maha Mendengar lagi Maha Mengetahui. Sesunguhnya aku telah ditipa penyakit dan Engkau adalah Tuhan yang Maha Penyayang.

\section{Kesimpulan}

Dari berbagai kota yang telah dikunjungi. Ada banyak kesan yang mendalam tentang jejak-jejak peradaban Islam di daratan benua Asia. Wilayah Cina ynag sangat luas di benua Asia bagian Utara tersimpan misteri jejak peradaban Islam. Ada beberapa peninggalan Islam hingga sekarang. Peninggalan Islam berupa masjid merupakan bagian dari adanya perkembangan Islam.

Masjid Niujiei dibangun pada 996 Masehi. Masjid Niujie terletak di Niujie, Distrik Xuanwu, Beijing. Masjid Niujie juga dilengkapi dengan menara. Menara tersebut digunakan sebagai penentu awal memasuki bulan Ramadhan. Menara tersebut juga sering kali digunakan untuk mengumandankan adzan.

Masjid Xi'an didirikan pada 742 Masehi. Tidak seperti kebanyakan masjid di Timur Tengah atau negara Arab lainnya, Masjid Raya Xi'an memiliki konstruksi dan gaya arsitektur yang berbeda, kecuali untuk beberapa huruf Arab dan dekorasi yang terdapat pada bangunan masjid. Masjid ini menjadi jejak para pedagang Arab dan Persia untuk berdakwah.

Komunitas muslim di Cina adalah suku minoritas Mereka berasal dari percampuran antara suku Han dengan pendatang dari Bukhara. Mereka bukan dari Arab, tetapi dari Asia tengah. Akibat percampuran tersebut, muslim Cina dikenal dengan komunitas suku Hui.

Beberapa nilai pendidikan Islam dalam novel Asslamaulaikum Beijing dapat dijadikan pelajaran untuk mengenal agama Islam. Berjilbab adalah pelindung bagi muslimat untuk menjaga diri. Hidayah berasal dari Allah SWT untuk umat yang dicintain-Nya. Kekuatan doa menjadi senjata dan kunci utama seorang muslim. 
Inilah bukti adanya jejak-jejak peninggalan peradaban Islam di benua Asia terutama dataran Cina. Dahulu Islam pernah menorehkan sejarah di negeri Tirai Bambu. Bahkan jejak-jejak peninggalan bersejaran berupa masjid masih berdiri kokoh dan dipergunakan sebagai sarana peribadatan kaum minoritas muslim di Cina. Bangunan Masjid dan perkampungan muslim menjadi bukti kejayaan Islam. 


\section{DAFTAR PUSTAKA}

Ahmad, Zainal Abidin. 1975. Riwayat Hidup Ibn Rusyd. Jakarta: Bulan Bintang.

A'la Al-Maududi, Abu. 1984. Khilafah dan Kerajaan Evaluasi Kritis Atas Sejarah Pemerintahan Islam. Jakarta: Mizan.

Ali, Syed Amiir. 1978. Api Islam.Jakarta: Bulan Bintang.

Amin, Ahmad. 1987. Islam dari Masa ke Masa. Bandung: CV Rusyda.

Atmosuwito, Subijantoro. 2010. Perihal Sastra dan Religius dalam Sastra. Bandung: Sinar Baru.

Bakar, Istianah Abu. 2008. Sejarah Peradaban Islam. Malang: UIN Press.

Bungi, Burhan 2007. Metodologi Penelitian Kualitatif. Jakarta: Raja Grafindo Persada.

Hassan, Ibrahim. 1990. Sejarah dan Kebudayaan Islam. Yogyakata: Kota Kembang.

Ibrahim, Rustam. 1971. Sejarah Islam. Jakarta: Djajamurni.

Moleong, J. Lexi. 1995. Metodologi Penelitian Kulaitatif. Bandung: PT Remaja Rosdakarya.

Mubarok, Achmad. 2002. Psikologi Dakwah. Jakarta: Pustaka Firdaus.

Nadia, Asma. 2015. Assalamualaikum Beijing. Depok: AsmaNadia Publishing House.

Rahmat, Jalaludin. 2000. Metode Penelitian Komunikatif. Bandung: Remaja Rosda Karya.

Semi, M. Atur. 1990. Metode Penelitian Sastra. Bandung: Angkasa.

Shihab, Alwi. 2001. Islam Sufistik: "Islam Pertama dan Pengaruhnya Hingga Kini di Indonesia. Bandung: Mizan. 
Ussairy, Ahmad 2003. Sejarah Islam Sejak Zaman Nabi Adam Hingga Abad ke XX. Jakarta: Akbar.

Watt, W. Montgomery. 1990. Kejayaan Islam: Kajian Kritis dari Tokoh Orientalis. Yogyakata: Tiara Wanaca

Wellek, Renne dan Austin Warren. 1990. Teori Kesusastraan. Terjemahan Melani Budiarta dari Theori of Literature (1997). Jakarta: Gramedia Pustaka Utama.

Yatim, Badri. 1993. Sejarah Peradaban Islam.Jakarta: PT Raja Grafindo. 